\title{
Effect of Tillage, Sowing Time and Irrigation Levels on Nutrient Uptake and Yield of Maize (Zea mays L.)
}

\author{
Archana Kumari ${ }^{1}$, Sanjay Kumar ${ }^{1}$, Mainak Ghosh ${ }^{1}$, Chandini ${ }^{1}$, Swaraj Kumar Dutta ${ }^{1}$, \\ Vinod Kumar $^{1 *}$, Amit Kumar Pradhan ${ }^{2}$ and Subrat Keshori Behera ${ }^{3}$
}

${ }^{1}$ Department of Agronomy, Bihar Agricultural University, Sabour, Bihar 813210

${ }^{2}$ Department of Soil Science and Agricultural Chemistry, BAU, Sabour, Bihar 813210

${ }^{3}$ Department of Statistics Mathematics and Computer Application, BAU, Sabour, Bihar

813210, India

*Corresponding author

\section{A B S T R A C T}

A field experiment was conducted during the rabi season of 2016-17at Research farm of Bihar Agricultural College, Sabour, to evaluate the effect of tillage, sowing time and irrigation levels on nutrient uptake and yield of maize (Zea mays L.).The experiment

\section{Keywords}

Zero tillage, Date of sowing, Maize nutrient content, Irrigation

\section{Article Info}

Accepted:

05 February 2020

Available Online:

10 March 2020 comprised of two tillage methods viz. conventional tillage (CT) and zero tillage (ZT) in main plot, two sowing dates- $30^{\text {th }}$ October and $10^{\text {th }}$ November as sub-plot and three irrigation levels $\left(I_{2}-2\right.$ irrigations at six-leaf stage and tasseling, $I_{4}-4$ irrigations at fourleaf stage, ten leaf stage, tasseling and milking and $\mathrm{I}_{6}-6$ irrigations at four-leaf stage, eight leaf stage, ten leaf stage, tasseling, milking and dough stage) as sub-sub plot treatment. The results indicated that the nutrient dynamics and productivity of rabi maize is significantly influenced by management practices. The higher nutrient content was recorded in CT maize stover and ZT maize grain and with 4 irrigations. However, maximum nutrient uptake and grain yield $\left(11.1 \mathrm{t} \mathrm{ha}^{-1}\right)$ was recorded in ZT system with six irrigation. Delay in sowing of rabi maize reduced the grain yield considerably at a rate of $121 \mathrm{~kg} / \mathrm{ha} /$ day. With increasing resource as well as crop management constraints, adoption of ZT along with residue retention and optimum water use has the potential of improving the nutrient uptake, nutrient use efficiency and crop productivity.

\section{Introduction}

In India, maize has been widely cultivated as a rainfed crop during kharif season but it can also be successfully grown during the rabi season as yield of rabi maize is considerably higher than that of kharif maize (Patel et al., 2006). The rabi maize has been widely accepted by farmers of Bihar with a cultivated area of 0.28 million ha with total production of 2.1 million tonnes (Directorate of Economics \& Statistics, 2018-19). To augment the higher maize yield per unit area and sufficient nutrient uptake, proper crop agronomic management is necessary. Sowing of the crop at right time ensures better plant 
growth, boosting the maize yield by increasing the resource use efficiency and also by inhibiting weed growth. Tillage system is an integral part of crop production and it has been confirmed by different scientists that conventional intensive tillage increases soil compaction, reduces soil aggregates stability, disrupts soil productivity, decreases retention and transportation of water and solutes and exacerbates losses due to run-off erosion (Goddard et al., 2008). In contrast many beneficial effects of zero-till and minimum tillage have also been reported like increased porosity, organic carbon, water holding capacity and decreased bulk density. It is well documented that zero tillage and crop residues management improves soil health and quality by improving various soil properties like reduced penetration resistance as well as the apparent density of soil that checks the soil evaporation rate (Rivas et al., 1998). Water infiltration and soil aeration that depend on bulk density are also modified (Rice et al., 1987). Zero tillage affects water availability to plants, essentially through soil water capture and root uptake capacity (Gajri et al., 1994; Ojeniyi, 1986). Zero tillage has also been reported to increase total nitrogen and microbial biomass in various soils (McCarty et al., 1995). The crop residues in zero tillage become a mulch over the soil surface that protects the soil productive layer against run-off reducing the nutrient loss and erosion through runoff (Perret et al., 1999, Smart and Bradford, 1999) and increases the percentage of organic matter in the superficial soil layer (Rivas et al., 1998; Roldan et al., 2003). Irrigation is another important management practice for higher crop production with better nutrient uptake which is mainly dependent on both irrigation frequency and total water application affecting root distribution and total root length (Robertson et al., 1980). This determines the vital plant physiological processes like cell elongation, cell division, cell wall synthesis, nitrate reductase activity and photosynthesis that are very sensitive to plant water status. Therefore, performance of a plant in terms of its growth, yield and nutrient content is mainly dependent on plant water status. Availability of optimum moisture in the soil enhances the efficiency of applied nutrients, and any reduction of soil moisture at these stages will considerably reduce the grain yield. The present investigation was carried out to evaluate the effect of tillage, sowing time and irrigation levels on nutrient concentration and uptake by maize and crop productivity.

\section{Materials and Methods}

A field experiment was conducted during the rabi season of 2016-17 at Bihar Agricultural University farm, Sabour $\left(25^{\circ} 15^{\prime} 40^{\prime \prime} \mathrm{N}\right.$, $87^{\circ} 2^{\prime} 42^{\prime \prime} \mathrm{E} ; 37 \mathrm{~m}$ above mean sea level), Bhagalpur, Bihar, India. The soil of the experimental field was sandy loam with neutral in reaction, medium in organic carbon $(0.6 \%)$ and available phosphorus $(35.2 \mathrm{~kg}$ $\mathrm{P}_{2} \mathrm{O}_{5} \mathrm{ha}^{-1}$ ), while low in available soil nitrogen (220.1 kg ha-1), and rich in soil potassium $\left(327 \mathrm{~kg} \mathrm{~K}_{2} \mathrm{O} \mathrm{ha}^{-1}\right.$ ). The experiment comprised of twelve treatment combinations laid out in split-split design with three replications. The two tillage methods viz. zero tillage $\left(\mathrm{T}_{1}-\mathrm{ZT}\right)$ and conventional tillage $\left(\mathrm{T}_{2}\right.$ $\mathrm{CT}$ ) were kept as main plots, while in sub-plot it was two sowing dates $\left(D_{1}-30\right.$ October and $\mathrm{D}_{2}-10$ November), and in sub-sub plot there were three irrigation levels i.e. $\mathrm{I}_{2}$ (2 irrigations at six-leaf stage and tasseling), $\mathrm{I}_{4}$ (4 irrigations at four-leaf stage, ten leaf stage, tasseling and milking) and $\mathrm{I}_{6}(6$ irrigations at four-leaf stage, eight leaf stage, ten leaf stage, tasseling, milking and dough stage). All the treatments received half nitrogen along with full dose of phosphorus and potassium as basal while the remaining $\mathrm{N}$ was top-dressed in two equal splits at knee-high and tasseling stage. The recommended dose of $\mathrm{N}: \mathrm{P}_{2} \mathrm{O}_{5}: \mathrm{K}_{2} \mathrm{O}$ 
for maize crop was kept as 150:75:50 $\mathrm{kg} \mathrm{ha}^{-1}$. The maize crop was sown on 30 October and 10 November in the year 2016 with a spacing of $60 \times 20 \mathrm{~cm}$ and harvested on 7 April and 20 April 2017, respectively. The plant samples for NPK analysis were collected at harvest stage. The Nitrogen content in dry matter was analysed by using micro-kjeldahl method (Tandon, 1993), phosphorus content by vanadomolybadate phosphoric acid yellow colour method (Jackson, 1973) and potassium content by flame photometer (Jackson, 1973).The N, P and K uptake were computed by multiplying nutrient content of grain and straw with respective dry weight $\left(\mathrm{kg} \mathrm{ha}^{-1}\right)$ at harvest stage. Grain and stover yield in each net plot was weighed and expressed in $\mathrm{kg} \mathrm{ha}^{-1}$. The experimental data recorded were analyzed statistically in split-split plot design to test the significance of the overall differences among treatments by using the $\mathrm{F}$ test and conclusions were drawn at 5\% probability level.

\section{Results and Discussion}

Nitrogen, phosphorus and potassium concentration in stover and grain of maize as influenced by differenttreatments

Results revealed that nitrogen content in both stover and grain was significantly affected by tillage practices and irrigation levels (table1). Conventional tillage (CT) recorded significantly higher values of nitrogen $(0.63 \%)$ and phosphorus content $(0.28 \%)$ in stover respectively. Grain nitrogen content recorded higher value with zero tillage (ZT) $(0.55 \%)$ whereas grain phosphorus content remained unaffected. On the contrary, date of sowing significantly affected only the phosphorous content in grain and the maximum phosphorus content for grain was recorded with $\mathrm{D}_{2}$ sowing $(0.31 \%)$ which was significantly higher than $\mathrm{D}_{1}$ sowing $(0.29 \%)$. In sub-sub plot, due to irrigation levels, nitrogen content of stover recorded higher value with $\mathrm{I}_{4}(0.63 \%)$ which was found to be at par with $\mathrm{I}_{6}(0.62 \%)$ and significantly higher than $\mathrm{I}_{2}(0.59 \%)$ whereas grain nitrogen content was significantly higher with $\mathrm{I}_{6}$ $(1.60 \%)$ followed by $\mathrm{I}_{4}(1.54 \%)$ and $\mathrm{I}_{2}(1.44$ $\%)$ irrigation levels respectively. The phosphorus content of stover was recorded higher with $\mathrm{I}_{6}(0.28 \%)$ followed by $\mathrm{I}_{4}(0.25 \%)$ and $\mathrm{I}_{2}(0.22 \%)$ whereas for grain phosphorus content was recorded higher with $\mathrm{I}_{6}(0.33 \%)$ followed by $\mathrm{I}_{4}(0.28 \%)$ and $\mathrm{I}_{2}(0.28 \%)$. The data of the potassium content of stover and grain was influenced only by different irrigation levels in sub-sub plot treatment. For stover, it was recorded higher with $\mathrm{I}_{6}(1.20 \%)$ which was at par with $\mathrm{I}_{4}(1.19 \%)$ and significantly higher over $\mathrm{I}_{2} \quad\left(\begin{array}{lll}1.13 & \%\end{array}\right)$ respectively. In grain, the potassium content followed a similar trend with higher values being recorded under $\mathrm{I}_{6}(0.69 \%)$ followed by $\mathrm{I}_{4}(0.67 \%)$ and $\mathrm{I}_{2}(0.64 \%)$ respectively. The $\mathrm{N}, \mathrm{P}$ and $\mathrm{K}$ content of maize grain and stover was significantly influenced due to tillage and irrigation levels. The maximum value of $\mathrm{N}, \mathrm{P}$ and $\mathrm{K}$ content was recorded under ZT with the highest level of irrigation applied with six irrigations. This could be attributed to the fact that ZT provided better soil environment for improved root development and also higher irrigation level ensured minimum water stress and also nutrient availability with increased forage area by the roots for nutrient extraction (Yadav et al., 2016). A similar pattern of nutrient content in maize crop under zerotillage based conservation agriculture practices have also been reported by other researchers (Alam et al., 2014; Naresh et al., 2014).

Total nitrogen, phosphorus and potassium uptake of maize as influenced by different treatments

The data recorded on the total uptake of nitrogen $(\mathrm{N})$, phosphorus $(\mathrm{P})$ and potassium 
(K) has been presented in table 2. The data revealed that tillage practices significantly influenced the higher nitrogen uptake with zero tillage $-\mathrm{T}_{2} \quad\left(203.6 \quad \mathrm{~kg} \quad \mathrm{ha}^{-1}\right)$ over conventional tillage $-\mathrm{T}_{1}\left(183.3 \mathrm{~kg} \mathrm{ha}^{-1}\right)$ compared to the other nutrients like phosphorus and potassium. Unlike tillage, the difference in date of sowing only significantly influenced the nitrogen uptake by the crop. Due to tillage, the maximum total nitrogen uptake was recorded with $\mathrm{D}_{1}$ sowing (202.1 $\mathrm{kg} \mathrm{ha}^{-1}$ ) which was significantly higher over $\mathrm{D}_{2}$ sowing $\left(184.9 \mathrm{~kg} \mathrm{ha}^{-1}\right)$. However, difference in irrigation application led to significant variation in $\mathrm{N}, \mathrm{P}$ and $\mathrm{K}$ uptake by the crop. In sub-subplot due to irrigation, maximum N, P and K uptake of 240, 69 and $146 \mathrm{~kg} \mathrm{ha}^{-1}$ was recorded with $\mathrm{I}_{6}$ (six irrigations) which was significantly higher over $\mathrm{I}_{4}$ and $\mathrm{I}_{2}$ irrigation levels respectively. However, tillage and time of crop establishment influence the nature of water utilization by the crop and therefore water productivity. Parihar et al., (2017) observed that the maize growth parameters were significantly $(p<0.05)$ superior under zero tillage and permanent bed compared to conventional tillage. Yadav et al., (2016) reported that $\mathrm{ZT}$ provided better soil environment for improved root development and also higher irrigation level ensured minimum water stress and also nutrient availability with increased forage area by the roots for nutrient extraction.

\section{Stover, grain and stone yield of maize as influenced by different tillage methods, date of sowing and irrigation levels}

The data on the yield of maize crop has been presented in table 3 . The data revealed that there was no significant difference in stover yield of maize due to individual effect of tillage, date of sowing and irrigation levels. However, grain yield differed significantly with tillage and recorded significantly higher grain yield under ZT (9164.9 $\mathrm{kg} \mathrm{ha}^{-1}$ ) as compared to CT (8043.2 $\mathrm{kg} \mathrm{ha}^{-1}$ ) which was 14 per cent more over CT. In sub-plot due to date of sowing, grain yield was significantly higher when sown on $\mathrm{D}_{1}-30^{\text {th }}$ October $(9270.6$ $\left.\mathrm{kg} \mathrm{ha}^{-1}\right)$ than $\mathrm{D}_{2}-10^{\text {th }}$ November $(7937.4 \mathrm{~kg}$ $\mathrm{ha}^{-1}$ ) sowing. Due to the early sowing of maize the yield was higher by 17 per cent and the yield decreased at a rate of $121 \mathrm{~kg} / \mathrm{ha} /$ day over early sown crop. In sub-sub plot significantly higher, grain yield was recorded with $\mathrm{I}_{6} \quad\left(11077.4 \quad \mathrm{~kg} \mathrm{ha}^{-1}\right)$ which was significantly higher over $\mathrm{I}_{4}\left(9565.5 \mathrm{~kg} \mathrm{ha}^{-1}\right)$ and $\mathrm{I}_{2}\left(5169.1 \mathrm{~kg} \mathrm{ha}^{-1}\right)$ irrigation levels. The significant yield increase with four irrigations $\left(\mathrm{I}_{4}\right)$ over $\mathrm{I}_{2}$ was 85 per cent while a further increase of two irrigations under $\mathrm{I}_{6}$, a 16 per cent increase in yield was recorded over $\mathrm{I}_{4}$ irrigation level. From the results, it can be concluded that zero tillage had a significant influence in increasing the crop yield followed by sowing time and irrigation levels. ZT in combination with earlier sowing and six irrigations produced the maximum yield. However, ZT of the early sown crop with four irrigations could also produce equivalent yield to that of $\mathrm{CT}$ plots under $\mathrm{D}_{1}$ sowing receiving six irrigations and also ZT with late sowing receiving six irrigations. The stone yield of maize did not vary significantly due to tillage methods or date of sowing. Due to irrigation application, the stone yield recorded higher values with $\mathrm{I}_{6}$ (six irrigations) (2920 $\mathrm{kg} \mathrm{ha}^{-1}$ ) which was statistically at par with $\mathrm{I}_{4}$ (four irrigations) (2635.2 $\left.\mathrm{kg} \mathrm{ha}^{-1}\right)$ and significantly higher over $\mathrm{I}_{2}$ (two irrigations) (1580.8 $\left.\mathrm{kg} \mathrm{ha}^{-1}\right)$. The higher yield of maize in ZT plots could be attributed to the multiple effects of nutrients added (Blanco-Canqui et al., 2009 and Kaschuk et al., 2010), comparatively lower weed pressure due to maintenance of surface residue (Ozpinar, 2015 and Chauhan et al., 2007), better water regimes promoting root growth and development (Govaerts et al., 2009) compared to CT. 
Table.1 Nitrogen, phosphorus and potassium concentration in stover and grain of maize as influenced by different tillage methods, date of sowing and irrigation levels

\begin{tabular}{|c|c|c|c|c|c|c|}
\hline \multirow[b]{2}{*}{ Treatment } & \multicolumn{2}{|c|}{ Nitrogen content (\%) } & \multicolumn{2}{|c|}{ Phosphorus content (\%) } & \multicolumn{2}{|c|}{ Potassium content $(\%)$} \\
\hline & Stover & Grain & Stover & Grain & Stover & Grain \\
\hline \multicolumn{7}{|c|}{ Tillage } \\
\hline$T_{1}$ & 0.63 & 1.51 & 0.28 & 0.30 & 1.19 & 0.68 \\
\hline $\mathbf{T}_{2}$ & 0.60 & 1.55 & 0.22 & 0.29 & 1.16 & 0.66 \\
\hline $\operatorname{SEm}( \pm)$ & 0.00 & 0.00 & 0.00 & 0.01 & 0.00 & 0.01 \\
\hline LSD (0.05) & 0.02 & 0.03 & 0.03 & NS & NS & NS \\
\hline \multicolumn{7}{|c|}{ Date of sowing } \\
\hline $\mathbf{D}_{1}$ & 0.61 & 1.52 & 0.25 & 0.29 & 1.17 & 0.66 \\
\hline $\mathbf{D}_{2}$ & 0.62 & 1.54 & 0.25 & 0.31 & 1.18 & 0.67 \\
\hline $\operatorname{SEm}( \pm)$ & 0.01 & 0.02 & 0.00 & 0.00 & 0.00 & 0.01 \\
\hline LSD (0.05) & NS & NS & NS & 0.01 & NS & NS \\
\hline \multicolumn{7}{|c|}{ Irrigation } \\
\hline $\mathbf{I}_{2}$ & 0.59 & 1.44 & 0.22 & 0.28 & 1.13 & 0.64 \\
\hline $\mathbf{I}_{4}$ & 0.63 & 1.54 & 0.25 & 0.28 & 1.19 & 0.67 \\
\hline$I_{6}$ & 0.62 & 1.60 & 0.28 & 0.33 & 1.20 & 0.69 \\
\hline SEm ( $( \pm)$ & 0.01 & 0.02 & 0.01 & 0.01 & 0.01 & 0.01 \\
\hline LSD (0.05) & 0.02 & 0.07 & 0.03 & 0.02 & 0.03 & 0.02 \\
\hline
\end{tabular}

$\mathrm{T}_{1}=$ Conventional Tillage; $\mathrm{T}_{2}$-Zero Tillage; $\mathrm{D}_{1}=30^{\text {th }}$ October; $\mathrm{D}_{2}-10^{\text {th }}$ November; $\mathrm{I}_{2}=$ Irrigation at $\mathrm{V}_{6}$ and tasseling; $\mathrm{I}_{4^{-}}$ Irrigation at $\mathrm{V}_{4}, \mathrm{~V}_{10}$, tasseling, milking; $\mathrm{I}_{6}$-Irrigation at $\mathrm{V}_{4}, \mathrm{~V}_{8}, \mathrm{~V}_{10}$, tasseling, milking, dough stage of the crop

Table.2 Total nitrogen, phosphorus and potassium uptake of maize as influenced by different tillage methods, date of sowing and irrigation levels

\begin{tabular}{|c|c|c|c|}
\hline Treatment & Total $\mathbf{N}$ uptake $\left(\mathrm{kg} \mathrm{ha}^{-1}\right)$ & Total $P$ uptake $\left(\mathrm{kg} \mathrm{ha}^{-1}\right)$ & Total K uptake $\left(\mathrm{kg} \mathrm{ha}^{-1}\right)$ \\
\hline \multicolumn{4}{|c|}{ Tillage } \\
\hline $\mathbf{T}_{1}$ & 183.3 & 52.9 & 119.3 \\
\hline $\mathbf{T}_{2}$ & 203.6 & 57.0 & 127.3 \\
\hline $\operatorname{SEm}( \pm)$ & 1.1 & 1.8 & 3.0 \\
\hline LSD (0.05) & 6.6 & NS & NS \\
\hline \multicolumn{4}{|c|}{ Date of sowing } \\
\hline $\mathbf{D}_{1}$ & 202.1 & 55.0 & 125.9 \\
\hline $\mathbf{D}_{2}$ & 184.9 & 54.9 & 120.7 \\
\hline $\operatorname{SEm}( \pm)$ & 1.3 & 1.0 & 2.0 \\
\hline LSD (0.05) & 5.3 & NS & NS \\
\hline \multicolumn{4}{|c|}{ Irrigation } \\
\hline $\mathbf{I}_{2}$ & 126.7 & 39.5 & 89.4 \\
\hline $\mathbf{I}_{4}$ & 213.7 & 56.6 & 134.8 \\
\hline $\mathbf{I}_{\mathbf{6}}$ & 240.0 & 68.7 & 145.6 \\
\hline $\operatorname{SEm}( \pm)$ & 3.1 & 1.3 & 1.7 \\
\hline LSD (0.05) & 9.4 & 3.9 & 5.2 \\
\hline
\end{tabular}


Table.3 Yield of maize as influenced by different tillage methods, date of sowing and irrigation levels

\begin{tabular}{|c|c|c|c|}
\hline Treatment & Stover yield $\left(\mathrm{kg} \mathrm{ha}^{-1}\right)$ & Grain yield $\left(\mathrm{kg} \mathrm{ha}^{-1}\right)$ & Stone yield $\left(\mathrm{kg} \mathrm{ha}^{-1}\right)$ \\
\hline \multicolumn{4}{|c|}{ Tillage } \\
\hline$T_{1}$ & 7403.4 & 8043.2 & 2107.2 \\
\hline $\mathbf{T}_{2}$ & 7412.0 & 9164.9 & 2650.1 \\
\hline $\operatorname{SEm}( \pm)$ & 398.2 & 55.4 & 105.6 \\
\hline $\operatorname{LSD}(0.05)$ & NS & 336.9 & NS \\
\hline \multicolumn{4}{|c|}{ Date of sowing } \\
\hline$D_{1}$ & 7165.7 & 9270.6 & 2499.4 \\
\hline $\mathbf{D}_{2}$ & 7649.7 & 7937.4 & 2257.8 \\
\hline $\operatorname{SEm}( \pm)$ & 394.2 & 154.9 & 65.5 \\
\hline $\operatorname{LSD}(0.05)$ & NS & 608.3 & NS \\
\hline \multicolumn{4}{|c|}{ Irrigation } \\
\hline $\mathbf{I}_{2}$ & 7183.4 & 5169.1 & 1580.8 \\
\hline $\mathbf{I}_{4}$ & 7820.7 & 9565.5 & 2635.2 \\
\hline$I_{6}$ & 7218.9 & 11077.4 & 2919.9 \\
\hline $\operatorname{SEm}( \pm)$ & 292.0 & 101.5 & 101.3 \\
\hline $\operatorname{LSD}(0.05)$ & NS & 304.3 & 303.6 \\
\hline
\end{tabular}

$\mathrm{T}_{1}=$ Conventional Tillage; $\mathrm{T}_{2}$-Zero Tillage; $\mathrm{D}_{1}=30$ October; $\mathrm{D}_{2}-10$ November; $\mathrm{I}_{2}=$ Irrigation at $\mathrm{V}_{6}$ and tasseling; $\mathrm{I}_{4^{-}}$ Irrigation at $\mathrm{V}_{4}, \mathrm{~V}_{10}$, tasseling, milking; $\mathrm{I}_{6}$-Irrigation at $\mathrm{V}_{4}, \mathrm{~V}_{8}, \mathrm{~V}_{10}$, tasseling, milking, dough stage of the crop

The findings of higher maize yield under ZT in close agreement with the findings of Yadav et al., (2016), Gathala et al., (2013), Parihar et $a l .$, (2016). The higher yield of maize under zero tillage system could be attributed to the compound effect of early establishment of the crop due to favorable moisture conditions in soil, additional nutrients (Blanco-Canqui et al., 2009 and Kaschuk et al., 2010), reduced competition for resources and improved biophysicochemical soil health as observed by previous researchers (Jat et al., 2013 and Govaerts et al., 2009) over conventional tillage system.

In conclusion, zero tillage was found to be an advantageous tillage practice in improving soil environment, facilitating maximum crop production while maintaining the soil health. In this experiment the zero tillage in combination with earlier sowing and six irrigations produced the maximum yield. Other interaction effect again confirmed that early sown maize with 4 irrigations under zero tillage system also has the potential to produce similar or higher grain yield compared to early sown maize with six irrigations under conventional tillage. This higher yield and nutrient uptake in ZT plots could be attributed to the multiple effects of added nutrient and organic matter, comparatively lower weed pressure due to maintenance of surface residue, better water regimes promoting root growth and development compared to CT. Nutrient uptake was recorded highest with early sowing of maize with 6 irrigations under ZT system. Early sowing ensures better crop establishment and ZT with higher irrigation level provides better bio-physicochemical soil health for improved root development ensuring better nutrient extraction with increased forage area.

\section{References}

Alam MK, Islam MM, Salahin N, Hasanuzzaman M (2014). Effect of 
tillage practices on soil properties and crop productivity in wheat-mungbeanrice cropping system under subtropical climatic conditions. Scientific World Journal, 10: 40-55.

Blanco-Canqui H, Lal R (2009). Crop residue removal impacts on soil productivity and environmental quality. CRC Crit. Rev. Plant Sci., 28:139-63.

Chauhan BS, Gill GS, Preston C (2007). Effect of seeding systems and dinitroaniline herbicides on emergence and control of rigid ryegrass (Lolium rigidum) in wheat. Weed Technol., 21: 53-8.

Directorate of Economics \& Statistics, 201819.

Gajri PR, Arora VK and Chaudhary MR (1994). Maize growth response to deep tillage, straw mulching and farmyard manure in coarse textured soils of NW India. Soil Use Manage. 10, 15-20.

Gathala MK, Kumar V, Sharma PC, Saharawat YS, Jat MS, Singh M, Kumar A, Jat ML (2007). Emergence and control of rigid ryegrass (Lolium rigidum) in wheat. Weed Technology, 21: 53-8.

Goddard T, Zoebisch M, Gaa, Ellis and WatlonAS(2008). No tillage farming system, world association on soil and water conservation. 39: 1

Govaerts B, Sayre KD, Goudeseune B, De Corte P, Lichter K, Dendooven L, Deckers J (2009). Conservation agriculture as a sustainable option for the central Mexican highlands. Soil and Tillage Research, 103: 222-30.

Jackson ML (1973). Soil Chemical Analysis, Vol.4 Prentice Hall of India Private Limited, New Delhi.

Jat SL, Parrihar CM, Sing AK, Jat ML, Jat RK (2014). Abstracts of 12th Asian Conference and Expert Consultation on Maize for Food, Feed, Nutrition and Environment.
Kaschuk G, Alberton O, Hungria M (2010). Three decades of soil microbial biomass studies in Brazilian ecosystems: lessons learned about soil quality and indications for improving sustainability. Soil Biol Biochem., 42:1-13.

McCarthy GW, Meisinger JJ and Jenniskens MM (1995). Relationship between total$\mathrm{N}$, biomass- $\mathrm{N}$ and active- $\mathrm{N}$ in soil under different tillage and $\mathrm{N}$ fertilizer treatments. Soil Biol. Biochem. 27, 1245-1250.

Naresh RK, Rathore RS, Kumar P, Singh SP, Singh A and Shahi UP (2014). The Indian Journal of Agricultural Sciences, 84(6), 105-109.

Ojeniyi SO (1986). Effects of zero-tillage and disk plowing on soil water, soil temperature and growth and yield of maize (Zea mays L.). Soil Tillage Res. 7, 173-182.

Ozpinar S (2015). Nutrient concentration and yield of maize (Zea mays L.) after vetch (Vicia sativa L.) in conventional and reduced tillage systems. Journal of Plant Nutrition, 39(12): 1697-1712.

Parihar CM, Jat SL, Singh AK, Kumar B, Yadvinder-Singh, Pradhan S, Pooniya V, Dhauja A, Chaudhary V, Jat ML, Jat RK and Yadav OP (2016). Conservation agriculture in irrigated intensive maizebased systems of north-western India: Effects on crop yields, water productivity and economic profitability. Field Crops Res, 193:104-16.

Parihar CM, Jat SL, Singh AK, Majumdar K, Jat ML, Saharawat YS, Pradhan S and Kuri BR (2017). Bio-energy, biomass water-use efficiency and economics of maize-wheat-mungbean system under precision-conservation agriculture in semi-arid agroecosystem, Energy, 119: 245-56.

Patel JB, Patel VJ and Patel JR (2006). Influence of different methods of irrigation and nitrogen levels on crop 
growth rate and yield of maize (Zea mays L.). Indian Journal of Crop Sciences. 1 (1\&2): 175-177.

Perret S, Michellon R and Tassin J (1999). Agroecological practices as tools for sustainable management of erosion of exposed tropical catchments: quantifying their effects on soil restoration and erosion control in Reunion island (Indian Ocean French Overseas Territories). In Sustainable Management of Tropical Catchment. Ed. D M T Herper Brown, Wiley, London; pp. 400.

Prasanna AL, Bairagya MD, Devi TM, Zaman AU (2019). Effects of Irrigation Regime and Nitrogen Level on Yield and Yield Attributes of Summer Maize (Zea mays L.). Int. J. Curr. Microbiol. App. Sci., 8(7):727-33.

Radford BJ, Dry AJ, Robertson LN and Thomas BA (1995). Conservation tillage increases soil water storage, soil animal populations, grain yield and response to fertilizer in the semiarid sub-tropics. Aust. J. Exp. Agric. 35, 223-232.

Rice CW, Grove HJ and Smith MS (1987). Estimating soil net nitrogen mineralization as affected by tillage and soil drainage due to topographic position. Can. J. Soil. Sci. 67, 513-520.

Rivas E, Rodriguez $M$ and Manrique $U$ (1998). Effecto de la labranza sobre las propriedades fisicas y quimicas del suelo y el rendimiento de maiz en los llanos altos del estado Monagas. Agron. Trop. 48, 157-174.

Robertson WK, Hammond LC, Johnson JT, and Boote KJ (1980). Effects of plantwater stress on root distribution of corn, soybeans, and peanuts in sandy soil. Agron. J., 72, 548-550.

Smart JR and Bradford JM (1999). Conservation tillage corn production for a semi-arid, subtropical environment. Agron. J. 91, 116-121.

Tandon HLS (1993). Methods of Analysis of soil, plant, water and fertilizers. Fertilizer Development and consultation organization, New Delhi.

Yadav MR, Parihar CM, Jat SL, Singh AK, Kumar, D, Pooniya V, Parihar MD, Saveipune D, Parmar $\mathrm{H}$ and Jat ML (2016). Effect of long-term tillage and diversified crop rotations on nutrient uptake, profitability and energetics of maize (Zea mays) in north-western India. Indian Journal of Agricultural Sciences, 86(6): 743-9.

\section{How to cite this article:}

Archana Kumari, Sanjay Kumar, Mainak Ghosh, Chandini, Swaraj Kumar Dutta, Vinod Kumar, Amit Kumar Pradhan and Subrat Keshori Behera. 2020. Effect of Tillage, Sowing Time and Irrigation Levels on Nutrient Uptake and Yield of Maize (Zea mays L.). Int.J.Curr.Microbiol.App.Sci. 9(03): 296-303. doi: https://doi.org/10.20546/ijcmas.2020.903.034 